\title{
A NEW ORNITHIDIUM (ORCHIDACEAE: MAXILLARIINAE) FROM THE MASSIF DE LA HOTTE OF HAITI
}

\author{
JAMES D. ACKerman ${ }^{1,3} \&$ W. MARK WhitTen ${ }^{2}$ \\ ${ }^{1}$ University of Puerto Rico, Faculty of Natural Sciences, Department of Biology and Center for Applied Tropical \\ Ecology and Conservation, PO Box 70377, San Juan, PR 00936-8377, USA \\ ${ }^{2}$ Florida Museum of Natural History, 385 Dickinson Hall, University of Florida, PO Box 117800, \\ Gainesville, FL 32611-7800, USA \\ ${ }^{3}$ Corresponding author: ackerman.upr@gmail.com
}

\begin{abstract}
A new species of Ornithidium from the Massif de la Hotte, one of the last remaining orchid-rich regions of Haiti, is described and illustrated. Collected in the 1980s by Donald D. Dod whose original specimen has been lost and whose live plants only just recently flowered, the new species is closely related to $O$. coccineum based on both morphology and molecular sequences. It is distinguished from the latter by shorter apical leaves, globose pseudobulbs and longer sepals..
\end{abstract}

KeY words: Greater Antilles, Orchidaceae, Ornithidium, Haiti, Donald D. Dod, orchid flora

In the mid 1980s, when Donald D. Dod (19122008) was working at the Jardín Botánico Nacional "Rafael Mosocoso" in Santo Domingo, Dominican Republic, he visited Pic Macaya National Park in the Massif de la Hotte, Haiti, with a scientific team from the University of Florida led by Walter S. Judd (see Dod 1984a,b, 1992, Dod \& Judd 1986, Judd 1987). Don was an extraordinary orchid collector. His meticulous field habits resulted in the discovery of numerous new species, many of which were small-flowered, inconspicuous pleurothallids. Some of the plants that he had collected from the trip to Pic Macaya National Park still exist in cultivation. One of them remained healthy but had been reluctant to flower. Don thought that it might be Ornithidium croceorubens Rchb.f. (Dod 1984b, Dod \& Judd 1986). The type of O. croceorubens hails from northern Haiti (Pic Macaya is in southwestern Haiti). It had been collected by L. C. Richard in the $19^{\text {th }}$ century, but the species had not been collected on the island since. Nobody paid much attention to it until Nir (2000) located the type at $\mathrm{W}$ and published a sketch of the flower and habit. We now regard $O$. croceorubens to be a synonym of Ornithidium inflexum (Lindl.) Rchb.f. As a consequence of our better understanding of $O$. croceorubens, it became abundantly clear that Don's plant was not what Nir had drawn, leaving Don's Ornithidium species without a nomenclatural home.
Several years ago Don graciously gave us a piece of his plant so that we could do some DNA sequence analyses at the University of Florida. Our plant died without flowering, but we did manage to amass enough sequence data to suggest that it was sister to Ornithidium coccineum (Jacq.) R.Br. After that, we shelved the problem hoping that Don's plants would flower.

Recently, as one of us (JDA) was wrapping up the Orchidaceae treatment for the Flora of the Greater Antilles (Ackerman in press), we decided to check on the status of Don's plant, hoping for more material. By this time, Don reached his 90's and it was time for changes so he transferred his live collection of plants to the University of California Botanical Garden in Berkeley where after about a year, the Ornithidium flowered! With the help of UCBG's Holly Forbes, we not only received additional material for more thorough sequencing but also pickled flowers to describe. Herein we propose this species as new to science and show its phylogenetic position within the Maxillariinae (generic concepts according to Blanco et al. 2007).

Ornithidium donaldeedodii Ackerman \& Whitten, sp. nov.

TYPE. Haitr: Dept. du Sud, Massif de la Hotte, Pic Macaya National Park, Formond, $18^{\circ} 22^{\prime} 57^{\prime \prime} \mathrm{N}$ $73^{\circ} 59^{\prime} 57^{\prime} \mathrm{W}$, discovered by Donald D. Dod, flowered 


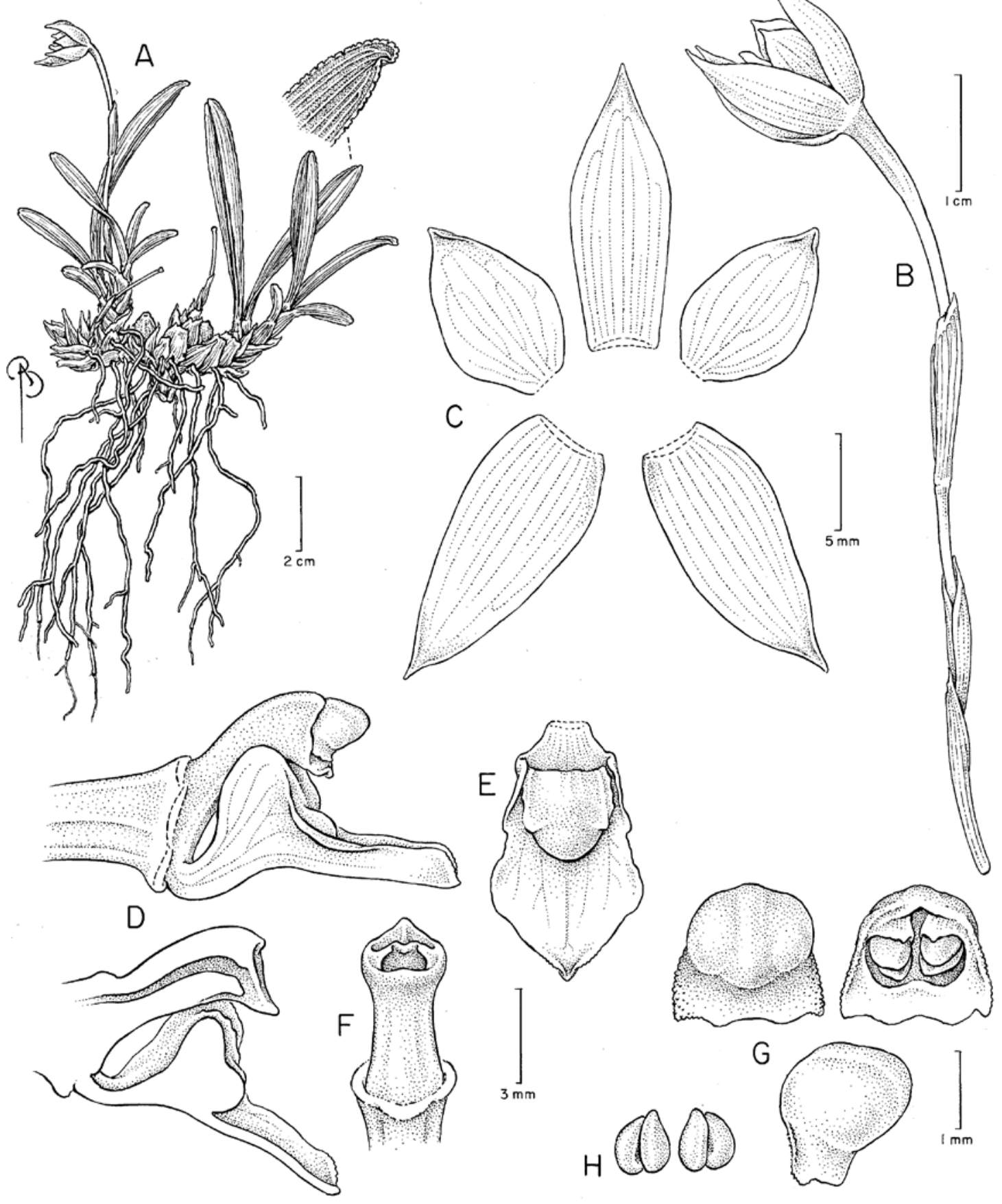

FiguRE 1. Ornithidium donaldeedodii Ackerman \& Whitten. A - Plant habit. B - Inflorescence, side view. C - Perianth parts: dorsal sepal, lateral petals and lateral sepals. D - Column and lip, side view and longitudinal section. E - Lip, dorsal view. F - Column without anther, ventral view. G - Anther, dorsal (left), ventral (right) and lateral views. H - Pollinia. (Drawn from the holotype.) Illustrated by Bobbi Angell. 
in cultivation at the University of California Botanical Garden, Berkeley, 8 May 2009, H. C. Forbes s.n. (holotype, UC; isotype, UPRRP). Fig. 1.

Usage synonym: Maxillaria croceorubens auct. non

(Rchb.f.) L.O. Williams: Dod in Moscosoa 3: 94, 102. 1984.

Ornithidium coccineum aemulans, differt foliis apicalibus brevibus sepalis longis et pseudobulbis globosis.

Epiphytic, caespitose herbs. Roots numerous, velamentous. Pseudobulbs green, slowly turning brown with age, globose, smooth, 1.0-1.5 $\mathrm{cm}$ diam., subtended by two foliaceous bracts. Leaves 1 from apex of pseudobulb, thin, ligulate, rounded-retuse, minutely crenulate at apex, slightly asymmetrical, 5-10 $\mathrm{cm}$ long, 6-10 $\mathrm{mm}$ wide, subtending pseudobulb bracts foliaceous and sometimes longer than apical leaf. Inflorescences one to several from new shoots, scapes $c a$. 10-11 mm long, single-flowered; floral bract scarious, brown with a hyaline apical margin, tightly sheathing the pedicellate ovary at base, inflated and loosely sheathing above, truncate, apiculate, $15 \mathrm{~mm}$ long. Flowers bright red to red-orange, campanulate; pedicellate ovary straight, $35-37 \mathrm{~mm}$ long, $1.3 \mathrm{~mm}$ diam. at apex of floral bract, $2.5 \mathrm{~mm}$ diam. below the perianth; sepals similar, dorsal sepal concaveto subcanaliculate, broadly elliptic-ovate, apically thickened, acuminate, $14-16 \mathrm{~mm}$ long, $5.5 \mathrm{~mm}$ wide at base, $6.6 \mathrm{~mm}$ wide near the middle when spread, lateral sepals slightly concave, ovate, acute and narrowing and thickening to a subacuminate apex, 15$16 \mathrm{~mm}$ long, $4.5 \mathrm{~mm}$ wide at base, $6.2 \mathrm{~mm}$ wide near the middle; petals slightly concave, broadly elliptical, abruptly acute with a slightly thickened apex, 9.5$10 \mathrm{~mm}$ long, $2 \mathrm{~mm}$ wide at base and $5-6 \mathrm{~mm}$ at the middle; labellum very fleshy, rigidly attached to the column foot, trilobed, slightly geniculate, $c a$. 7.5 $\mathrm{mm}$ long, claw concave, $c a .1 \mathrm{~mm}$ long, lateral lobes erect, just reaching the sides of the column to flank the stigma, convex, oblong, rounded, $3.5 \mathrm{~mm}$ long, $2 \mathrm{~mm}$ wide, mid lobe ovate, acute, somewhat flat, $5 \mathrm{~mm}$ long, $4 \mathrm{~mm}$ wide, callus yellowish, nearly filling the space between the lateral lobes, spilling glacier-like down to the base of the mid lobe ending in a minutely warty, rounded bump; column semiterete, erect, arched just below stigma, $4.5 \mathrm{~mm}$ long measured dorsally (less anther cap), $6 \mathrm{~mm}$ long measured ventral from the tip of the column foot to the rostellum, $2 \mathrm{~mm}$ diam. at the base, $1.7 \mathrm{~mm}$ diam. just below the stigma, 2.4 $\mathrm{mm}$ diam. across the deeply concave stigma, pollinia 4, flattened, ovate. Fruits unknown.

Etymology: Named in honor of "Don" Donald D. Dod (see Jiménez 2003) whose name graces numerous species of Hispaniolan orchids, but none in this form. After a long and fulfilling journey, Don died in 2008.

We compared photographs and pickled flowers of O. donaldeedodii from the University of California Berkeley Botanical Garden collection to fresh, pickled and pressed specimens of $O$. coccineum from the UPRRP herbarium (Dominican Republic: Prov. San Cristóbal, Cordillera Central, Jimenez, Mejía, \& Veloz 1362; Prov. Barahona, Sierra Baoruco, Ackerman, Williams, Tremblay \& Higgins 3294; Prov. La Vega, Reserva Cientifica Ebano Verde, Ackerman, Carromero \& Dod 2941; Puerto Rico: Mun. Barranquitas, Cerro La Torrecilla, Ackerman 2360; Ackerman \& Zimmerman 2674; Axelrod \& Ackerman 746; Rodríguez 16; Mun. Ponce, Toro Negro Forest Reserve, Axelrod \& Chavez 4327; Mun. Patillas, Carite Forest Reserve, Axelrod 7632; Tropic Ventures, Taylor \& Scott 7411; Mun. San Lorenzo-Patillas, Carite Forest Reserve, Axelrod \& Gust 12962; Mun. Río Grande, Luquillo Mountains, Ackerman \& Montalvo 1644; Ackerman \& Ackerman 4216; Axelrod, Ackerman \& Zimmerman 4395; Ackerman 4494; García Ruiz 14; Mun. Naguabo, Luquillo Mountains, Ackerman, Gaa, Montalvo \& Parrilla 1820; Axelrod, Fritsch \& Santiago 12551; Mun. Río Grande-Naguabo, Luquillo Mountains, Ackerman 1930). Dod (1984b) cited his collection, Dod 906, at JBSD, but Francisco Jiménez of JBSD was unable to locate it for us.

The flowers of Ornithidium donaldeedodii are similar to $O$. coccineum in both color and form. The two species differ in at least the following characteristics. The apical leaves of $O$. donaldeedodii are rather short, 5-10 $\mathrm{cm}$ long, whereas those of $O$. coccineum are very rarely as short as $10 \mathrm{~cm}$ and reach to $45 \mathrm{~cm}$ in length. Lateral sepals of the former are about $16 \mathrm{~mm}$ long while those of the latter are 11-12.5 mm long, at least in the Greater Antilles. While the more familiar $O$. coccineum has dark green pseudobulbs that are distinctively compressed 


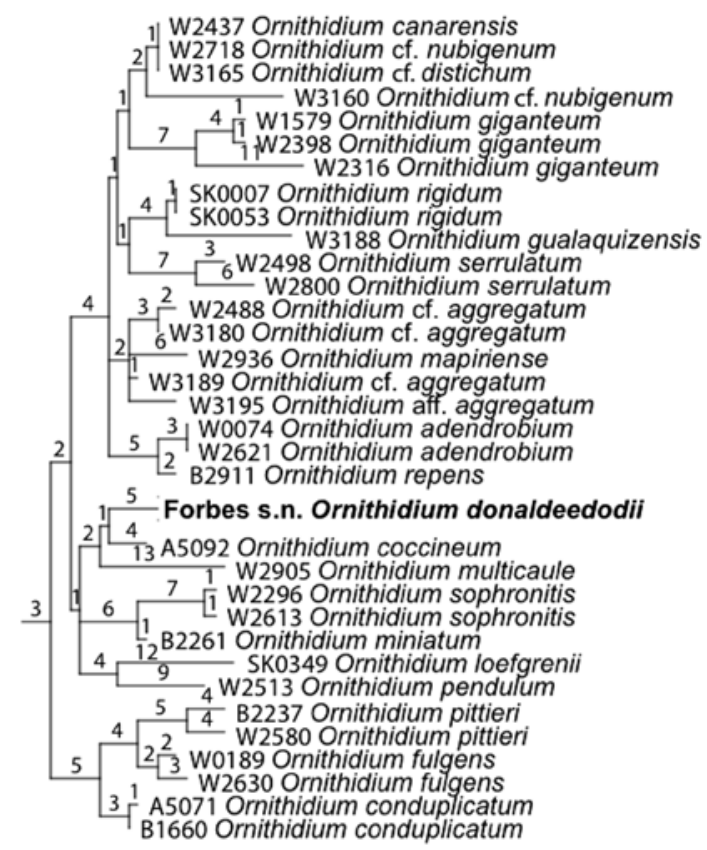

FIGURE 2. A molecular phylogeny of Ornithidium including $O$. donaldeedodii based upon parsimony analyses of nrITS sequences; analyses are adapted from those of Whitten et al. 2007. Numbers above branches are branch lengths.

laterally and wrinkle with age, those of $O$. donaldeedodii are a light green, globose, smooth and do not appear to darken and wrinkle with age. Dod (1984b) contradicts our description in the length of the sepals and we can only say that he must have gotten the differences reversed. The flowers are slightly more compressed laterally but one must have both species in hand to see that. $\mathrm{He}$ also mentioned that this species has tightly caespitose pseudobulbs, which is true, but the pseudobulbs of young flowering plants of $O$. coccineum are like that as well. For detailed descriptions of $O$. coccineum, see Ackerman (1995, in press) and Nir (2000).

To assess its phylogenetic distinctiveness and placement within Ornithidium, we sequenced two accessions of $O$. donaldeedodii (probably divisions of the type material) for the nrITS DNA region, following protocols and data matrix in Whitten et al. 2007. The resulting sequences are identical. GenBank numbers are GU177874 Forbes s.n. (UC) and GU177875 Whitten 3593 (FLAS). The resulting cladogram (FIg. 2) confirms its placement within Ornithidium Salisb. ex $\mathrm{R}$. Br. and its distinctiveness from $O$. coccineum.
AcKnOwledgements. The authors thank the ghost of Donald D. Dod for providing us with samples of his Ornithidium, and Holly Forbes for her help at the UC Botanical Garden. Bobbi Angell did the drawing for which we are very grateful. Mario Blanco reviewed the manuscript for which we are appreciative. We also thank Francisco Jiménez who had searched JBSD for Dod 606. Funding was provided by U.S. National Science Foundation grants No. DEB-0234064 to N. H. Williams and W. M. Whitten, and No. HRD-0734826 to E. Cuevas. Additional funding was provided by a Furniss Foundation graduate student fellowship from the American Orchid Society to M. A. Blanco and by Kew Latin American Research Fellowships to M. A. Blanco.

\section{Literature Cited}

Ackerman, J.D. 1995. An orchid flora of Puerto Rico and the Virgin Islands. Mem. New York Bot. Gard. 73.

Ackerman, J.D. In press. Flora of the Greater Antilles: Orchidaceae. Mem. New York Bot. Gard.

Blanco, M.A., G. Carnevali, W. Mark Whitten, R.B. Singer, S. Koehler, N.H. Williams, I. Ojeda, K.M. Neubig, \& L. Endara. 2007. Generic realignments in Maxillariinae (Orchidaceae). Lankesteriana 7: 515-537.

Dod, D.D. 1984a. Massif de la Hotte, isla peculiar: orquídeas nuevas iluminan su historia. Moscosoa 3: 91-99.

Dod, D.D. 1984b. Orquídeas (Orchidaceae) nuevas para La Española y otras notas. V. Moscosoa 3: 100-120.

Dod, D.D. 1992. Orchids in the land that Columbus loved. Amer. Orchid Soc. Bull. 61(10): 966-979.

Dod, D.D. \& W.S. Judd. 1986. The Orchidaceae of La Visite and Macaya National Parks, Haiti. Grant Report for USAID/Haiti under contract No. 521-0169-C-00308300. Gainesville, Florida. Available online at http://pdf. usaid.gov/pdf_docs/PNAAV074.pdf

Jiménez, F. 2003. Datos biográficos de Donald Dungan Dod. Moscosoa 13: 1-5.

Judd, W.S. 1987. Floristic survey of Morne La Visite and Pic Macaya National Parks, Haiti. Bull. Florida State Mus., Biol. Sci. 32: 1-136.

Nir, M. 2000. Orchidaceae Antillanae. DAG Media Publishing, New York.

Whitten, W.M., M.A. Blanco, N.H. Williams, S. Koehler, G. Carnevali, R.B. Singer, L. Endara, \& K. Neubig. 2007. Molecular phylogenetics of Maxillaria and related genera (Orchidaceae: Cymbidieae) based upon combined molecular data sets. Amer. J. Bot. 94: 18601889. 